\author{
Alina Szwarc \\ ORCID: 0000-0002-3075-5872
}

\title{
Treści kształcenia w perspektywie przemian edukacyjnych
}

Treści kształcenia, niezależnie od przyjętej perspektywy ich postrzegania, stanowią jedno z najważniejszych, ale i najbardziej skomplikowanych elementów systemu kształcenia. Analiza literatury pedagogicznej wskazuje, iż w zasadzie to nie czas, ale określona przestrzeń decydowała (i wciąż decyduje) o istocie i roli treści w edukacji. Od zawsze bowiem poszukiwanie prawidłowości i podstaw w tworzeniu kanonu wiedzy szkolnej stanowiło ogromne wyzwanie naukowe. Treści realizowane w szkołach są wynikiem teoretycznej koncepcji procesu kształcenia, ustroju szkolnego, ale i stanu rozwoju nauki, uwarunkowań społecznych, kulturowych czy politycznych ${ }^{1}$. Jednakże, niezależnie od tych czynników, które przecież tylko w jakimś stopniu wyznaczają treść edukacji, istnieją również uwarunkowania uniwersalne, które należy respektować w każdym systemie dydaktycznym, ale i w każdych warunkach społecznych. Z całą pewnością należą do nich te, jakie związane są z człowiekiem (dzieckiem, uczniem) i jego rozwojem. Stąd w niniejszym artykule analizie poddaję zagadnienie treści

1 Por. W. Okoń, Nowy słownik pedagogiczny, Wydawnictwo Akademickie Żak, Warszawa 2004, s. 428; Idem, Wprowadzenie do dydaktyki ogólnej, Wydawnictwo Akademickie Żak, Warszawa 2003; B. Milerski, B. Śliwerski (red.), Pedagogika. Leksykon PWN, Wydawnictwo Naukowe PWN, Warszawa 2000, s. 251; A. Siemak-Tylikowska, Treści nauczania - teorie doboru treści kształcenia, [w:] W. Pomykało (red.), Encyklopedia pedagogiczna, Wydawnictwo Naukowe PWN, Warszawa 1997, s. 853-854. 
kształcenia, ukazując główne tendencje w ich postrzeganiu w kontekście przemian procesu dydaktyczno-wychowawczego, uwzględniając wymienione kategorie i kryteria edukacyjne. Jednocześnie, zdając sobie sprawę z powierzchowności poczynionych analiz, spróbuję przyjrzeć się elementom scalającym te zagadnienia, które - w przypadku treści edukacyjnych - wydają się być ponadczasowe.

Już Jan Amos Komeński rozwój człowieka upatrywał w wychowaniu kreowanym przez „obiektywne wymagania wiedzy i społeczeństwa, przez rozwijanie jego umysłu i jego umiejętności działania dla dobra ogółu. Komeński usiłował (...) walczyć z istniejącym porządkiem społecznym dlatego, aby każde dziecko miało możność pełnego rozwoju i możność stania się człowiekiem"2.

$\mathrm{Z}$ tego zapewne powodu, w swoich poglądach na temat treści, wyraźnie zaznaczał, iż powinny obejmować one to wszystko, co jest ważne dla ludzi. Jak pisał: „,...) choć nie wszyscy mają być w przyszłości rękodzielnikami, gońcami, pisarzami, mówcami, tak też i w szkole powinno się wszystkich uczyć wszystkiego, co należy do człowieka, choć jednym jedne, a innym inne rzeczy bardziej się w przyszłości przydadzą"3. Wielokrotnie w swoich pracach podkreślał, iż ludzka mądrość może się kształtować tylko na podstawie rozumienia przyrody i społeczeństwa. Natomiast charakterystyczną cechą pedagogicznych poglądów Komeńskiego stał się postulat powszechności kształcenia. W swoich pracach wielokrotnie wskazywał, iż dobór treści ma związek przede wszystkim z poziomem rozwoju człowieka, z jego wiekiem. Wiele uwagi przywiązywał do organizacji procesu kształcenia, propagując ideę czwórdzielnej budowy szkół. Jej istotę opierał na porównaniu szkół do czterech pór roku: szkołę macierzyńską do wiosny, szkołę elementarną do lata, gimnazjum do jesieni, natomiast akademię do zimy. Niezależnie jednak od etapu i rodzaju szkoły, do głównych treści (zwanych przez niego materiałem) zaliczał takie, które spowodują, by: „a) umysły uszlachetniały się naukami i sztukami, b) by doskonaliły się języ-

2 B. Suchodolski, Wstęp, [w:] J.A. Komeński, Wielka dydaktyka, Wydawnictwo Polskiej Akademii Nauk, Wrocław 1956, s. XCVIII.

3 J.A. Komeński, Wielka dydaktyka..., s. 82. 
ki, urabiały się obyczaje w kierunku wszechstronnej moralności, d) a Bóg był czczony z głębi serca"4. Stąd refleksje Komeńskiego w dużym stopniu dotyczyły organizacji edukacji. W swoich rozważaniach pedagogicznych wskazywał na te uwarunkowania, które dotyczą głównie sposobów pracy z uczniami, choć - jak wiadomo - opierały się one wówczas na strategii podającej. Zauważał, iż

alfą i omegą ma być: badanie i znalezienie sposobu, który by pozwalał, ażeby nauczyciele mniej nauczali, a uczniowie więcej się uczyli, ażeby w szkołach było mniej hałasu, nudy i bezpłodnych wysiłków, a więcej spokoju, przyjemności i gruntownych postępów w pracy, w państwie zaś aby mniej było ciemnoty, zamieszania i niezgody, a więcej światła, porządku, pokoju i ciszy ${ }^{5}$.

Wiele zmian w spojrzeniu na treści zdecydowanie przyniosło nowe wychowanie, którego założenia okazały się bliskie poglądom wielu wybitnych przedstawicieli myśli dydaktycznej ubiegłego wieku6 ${ }^{6}$ I tak, już Bogdan Nawroczyński w swoich pracach przekonuje o znaczeniu przeszłości, historii i poglądów jego poprzedników w poszukiwaniu ideałów dydaktycznych. Autor w wielu miejscach zakłada, iż głoszenie postulatów nowego wychowania i szkoły przyszłości, nie byłoby możliwe, gdyby nie uwzględniać, ale i analizować dorobku naukowego przeszłości. Jak pisał: „Obrałem tę do syntezy drogę, rozumiejąc, iż fragmentaryczność współczesnej myśli pedagogicznej jest skutkiem zajmowania się głównie metodami i organizacją pracy wychowawczej przy jednoczesnym traceniu z oczu jej celu"7. A cel ten dotyczył kształtowania osobowości człowieka, tak by mógł stać się on samodzielnym i twórczym członkiem społeczeństwa. Analiza literatury wskazuje, iż już wówczas więcej uwagi przywiązywano do poszukiwania kanonu treści przedmiotowych w kształceniu ogólnym, niż do samego pojęcia treści (choć nazywanych często materiałem naukowym). Poddawano zatem analizom czynniki ich doboru takie jak wiek, poziom rozwoju umysłowego

\footnotetext{
Ibidem, s. 76-77.

J.A. Komeński, Wielka dydaktyka..., s. 4.

Szerzej na ten temat piszę w: A. Szwarc, Treści kształcenia jako element programu szkolnego w poglądach wybitnych pedagogów pierwszej połowy XX wieku, „Przegląd Historyczno-Oświatowy" 2019, nr 3-4, s. 91-99.

7 B. Nawroczyński, Zasady nauczania, Wydawnictwo Książnica - Atlas, Lwów - Warszawa 1930, s. 4.
} 
ucznia (o których przecież pisał już Komeński) czy potrzeby określone w „programie naukowym”. Jak czytamy, szkoła kształtuje

umysły dzieci w toku przyswajania materiału nauczania objętego programem, przy czym szczególną uwagę zwraca na wyrabianie umiejętności samodzielnego wnioskowania oraz rozumienia zjawisk zarówno przyrodniczych, jak i społecznych zgodnie z materialistycznym poglądem na świat. Szkoła budzi zamiłowanie do wiedzy, wdraża do pracy, do aktywności społecznej i kultury życia codziennego ${ }^{9}$.

Analizom zatem poddawane były przedmioty szkolne (tworzące tok nauki), jak i ich same treści, stanowiące tzw. tok szczegółowy ${ }^{10}$. Wiele uwagi w kontekście doboru materiału poświęcano etapom edukacyjnym, zagadnieniom społecznej roli szkoły ${ }^{11}$, istocie wiadomości i sprawności w nauczaniu, ale i samym analizom ówczesnych treści, choć przez pryzmat dominujących w tamtych latach podających metod kształcenia ${ }^{12}$.

Szkoła, a w zasadzie panujący w niej system kształcenia, od zawsze poddawane były krytyce. Jednak, jak podaje Wincenty Okon' ${ }^{13}$, szczególnie widoczna i ostra była ta krytyka pod koniec XX wieku. W dużej mierze była wynikiem

zwiększania się dystansu między szybko, pod wpływem postępu naukowo-technicznego, zmieniającym się życiem społecznym a stosunkowo małymi zmianami w systemach kształcenia, na skutek czego starorzymskie hasło "non vitae sed scholae discimus" (uczymy się nie dla życia, ale dla szkoły - dop. A.S.) nabiera coraz większej ostrości. Jest to krytyka uzasadniona, lecz wykazująca dość wiele bezradności ${ }^{14}$.

$8 \quad$ Por. Ministerstwo Oświaty, Program nauczania w szkole podstawowej, Państwowe Zakłady Wydawnictw Szkolnych, Warszawa 1959.

9 Ibidem, s. 7.

10 K. Sośnicki, Zarys dydaktyki, Wydawnictwa Książek Szkolnych Kuratorjum Okręgu Szkolnego Lwowskiego, Lwów 1925.

11 S. Hessen, Struktura i treść szkoły współczesnej (zarys dydaktyki ogólnej), Nasza Księgarnia, Warszawa 1947.

12 B. Nawroczyński, Zasady nauczania...

13 W. Okoń, Wprowadzenie...

14 Ibidem, s. 62. 
A przecież to właśnie poszukiwanie nowych rozwiązań, nowych systemów kształcenia wydaje się najważniejsze w czasach zmieniających się warunków życia społecznego. Zapewne też z tego powodu wiele istotnych zmian $\mathrm{w}$ badaniach nad treściami nastąpiło po drugiej wojnie światowej, w wyniku ważnych przeobrażeń społeczno-gospodarczych i kulturowych, kiedy sprawy edukacji - zwłaszcza szkolnictwa - stały się przedmiotem zainteresowania zarówno świata nauki, jak i szerokiej opinii społecznej. Obowiązujące wówczas treści, zawarte w ówczesnym programie nauczania, zostały poddane ostrej krytyce. Najintensywniejsze prace w tym zakresie (podejmowane zresztą nie tylko w Polsce) przypadały na lata sześćdziesiąte i siedemdziesiąte ubiegłego wieku ${ }^{15}$. Zdaniem Krzysztofa Kruszewskiego, wiele wartościowych danych z zakresu treści wniosła książka autorstwa Wincentego Okonia Podstawy wykształcenia ogólnego, w której autor podjął zagadnienie uczenia się szkolnych przedmiotów. To w tej pracy „dopiero treść kształcenia posłużyła określaniu procesów dydaktycznych i integrowaniu dydaktyki”"16.

Kolejny przełom w myśleniu o treściach, wiązał się z przemianami, jakie nastąpiły w naszym kraju po 1989 roku. Gruntownych ich regulacji, zwłaszcza w zakresie obowiązującej wówczas dokumentacji oświatowej, dokonano w 1999 roku, w wyniku reformy systemu oświaty ${ }^{17}$. Skoncentrowano się wówczas na usunięciu z programu wielu nieaktualnych treści, natomiast wyeksponowano istotę m.in. umiejętności samodzielnego myślenia, pozyskiwania, selekcjonowania i przetwarzania informacji ${ }^{18}$. Jak się okazuje, i do dziś wszelkie zmiany w treściach wiążą się wyłącznie ze zmianami oświatowymi (które w naszym kraju są dokonywane bardzo często $)^{19}$. W perspektywie definicyjnej pojęcia

15 C. Kupisiewicz, Charakter i treść kształcenia powszechnego: podstawowego i średniego, [w:] M. Berge, T. Lewowicki (red.), Optymalizacja treści i procesu kształcenia, Wydawnictwo Uniwersytetu Warszawskiego, Warszawa 1992.

16 K. Kruszewski, Zmiana i wiadomość. Perspektywa dydaktyki ogólnej, Państwowe Wydawnictwo Naukowe, Warszawa 1987, s. 12.

17 Szerzej na ten temat np. K. Konarzewski, Reforma oświaty. Podstawa programowa i warunki kształcenia, Instytut Spraw Publicznych, Warszawa 2004.

18 C. Kupisiewicz, Projekty reform edukacyjnych w Polsce, Wydawnictwo Naukowe PWN, Warszawa 2006.

19 Największe zmiany zostały wprowadzone w wyniku reformy programowej w 2008 roku oraz ostatniej reformy systemu oświaty, której założenia wprowadzono do szkół 1 września 2017 roku. 
treści, wydarzenia te jednak niewiele zmieniły. Okazuje się bowiem, iż treści do dziś zwykle utożsamiane są z materiałem, jaki przewidziany jest do realizacji w pracy nauczyciela z uczniami ${ }^{20}$, podczas gdy wielu autorów od dawna wskazuje na podstawowe różnice w pojmowaniu tych terminów ${ }^{21}$. Wyraźnie akcentowane to jest od lat w dokumentacji oświatowej, czego doskonałym przykładem jest ostatnia podstawa programowa, której zarówno struktura, jak i zastosowane kategorie pojęciowe, bardziej przypominają Program nauczania w szkole podstawowej z 1959 roku niż dokument na miarę współczesnej dydaktyki.

Wiele cennych uwag w kierunku treści kształcenia odnaleźć można w pracach Krzysztofa Kruszewskiego. Już w latach osiemdziesiątych ubiegłego wieku pisał, iż w płaszczyźnie definicyjnej pojęcie treści kształcenia rozpatrywać można w wielu kontekstach, dotyczących zarówno zakresu analizowanych zjawisk, układów zmiennych, jak i przyjętej podstawy teoretycznej22. Można oczywiście przyjąć, iż w wąskim ujęciu treści stanowią uporządkowany zasób informacji i czynności, których opanowanie powinno umożliwić człowiekowi ukształtowanie odpowiednich stosunków z otaczającym go światem ${ }^{23}$. Ale w ostatnich dziesięcioleciach powstało wiele koncepcji naukowych, które - w odniesieniu do problematyki treści kształcenia - dostarczyły nowych płaszczyzn badawczych, a tym samym stały się podstawą do szerszych ujęć treści, również w zakresie definicyjnym ${ }^{24}$. W dużej mierze przyczyniły się do tego prace Lwa Wygotskiego, czego dowodem są badania prowadzone przez rosyjskich pedagogów i psychologów ${ }^{25}$. Wśród teorii socjokulturowych wyróżnić należy poglądy Jerome’a Brunera, który zaprojektował i uzasadnił m.in. spiralny układ treści. Podkreślić należy, iż powyższe teorie do dziś dla wielu autorów są inspiracjami do konstruowania projektów badawczych dotyczących zmian w edukacji

20 K. Kruszewski, Od ttumacza, [w:] D.F. Walker, J.F. Soltis, Program i cele kształcenia, Wydawnictwa Szkolne i Pedagogiczne, Warszawa 2000.

21 Por. m.in. K. Kruszewski (red.), Sztuka nauczania. Czynności nauczyciela, Wydawnictwo Naukowe PWN, Warszawa 2007.

22 Idem, Wykorzystanie teorii wiadomości $w$ studiach nad treściami kształcenia, [w:] M. Berge, T. Lewowicki (red.), Optymalizacja treści...

23 W. Okoń, Nowy słownik...

24 K. Kruszewski, Wykorzystanie teorii wiadomości...

25 Szerzej na ten temat: K. Kruszewski, Zmiana i wiadomość... 
i procesie kształcenia ${ }^{26}$. Ponadto we współczesnym rozumieniu treści wiele wniosły poglądy Davida Ausubela, który opracował procedurę organizowania treści przydatnych $\mathrm{w}$ opanowaniu nowego materiału. Autor postrzega treści jako nieprzypadkowy zbiór wiadomości, który w trakcie czynności uczenia się traktowany jest jako indywidualna i niepowtarzalna struktura ${ }^{27}$. Wśród polskich badaczy wskazać należy poglądy m.in. Wincentego Okonia (dotyczące teorii kształcenia wielostronnego), Czesława Kupisiewicza (będące efektem prowadzonych badań nad niewłaściwą pracą z materiałem) czy Tadeusza. Lewowickiego (związane $\mathrm{z}$ indywidualizacją kształcenia). $\mathrm{Z}$ pewnością wiele $\mathrm{z}$ powyższych poglądów przyczyniło się do szerszych interpretacji treści. Należy do nich propozycja Krzysztofa Kruszewskiego, którego naukowe rozważania, ale i prowadzone badania, wyznaczyły treściom kształcenia centralne miejsce w dydaktyce. Autor już ponad trzydzieści lat temu zauważył, iż treści łączą przede wszystkim „kwestie celów kształcenia i pomiaru dydaktycznego, procesów psychicznych, które zachodzą u osób uczących się, i sterowania tymi procesami (proces kształcenia), metod oraz organizowania całej sytuacji dydaktycznej, w której znajduje się i działa uczen" ${ }^{28}$.Zdaniem Kruszewskiego: „wiedza człowieka nie jest odbiciem materiału nauczania, nie jest odbiciem układu wiadomości wprowadzonych do pamięci w wyniku pracy nad materiałem nauczania. Jest inna i jakoś funkcjonuje, gdy uczeń poznaje następną partię materiału"29. Stąd Kruszewski odnosi treść do wiadomości, bowiem „wiadomości znaczą, gdy mają treść" ${ }^{30}$. W procesie kształcenia wiadomości mogą wystąpić w kilku formach, do których należą:

1) materiał nauczania, czyli wiadomości, z którymi uczeń ma się zetknąć i wiadomości dostarczone mu,

2) wiadomości odebrane przez ucznia, odtworzone z materiału nauczania oraz poddane reorganizacji,

3) wiadomości wytworzone przez ucznia,

26 E. Filipiak, „Produkty” kultury uczenia się uczniów szkoły podstawowej i gimnazjum, „Forum Oświatowe” 2012, nr 1 (46), s. 159.

27 E. Piotrowski, Rola treści kształcenia w procesie nauczania, „Chowanna. Tom Jubileuszowy" 2009, s. 153-159.

28 K. Kruszewski, Zmiana i wiadomość..., s. 105-106.

29 Ibidem, s. 31.

30 Ibidem, s. 30. 
4) wiadomości znajdujące się w pamięci ucznia jako wiedza, które mogą być uświadamiane lub nieuświadamiane ${ }^{31}$.

Autor proponuje trzy ujęcia treści kształcenia, które stanowiąc podstawę różnych koncepcji, wywołują inne postępowanie praktyczne $\mathrm{i}$ badawcze. Każde $\mathrm{z}$ nich wynika również $\mathrm{z}$ innej refleksji nad doborem treści traktowanych jako:

1) uporządkowany zbiór wiadomości o niezależnym od ucznia i kontekstu znaczeniu;

2) uporządkowany (planowany) ogół wszystkich doświadczeń ucznia w szkole, obejmujących tak wiadomości, jak i jego przeżycia;

3) uporządkowany zbiór wiadomości lub/i doświadczeń, dzięki którym osiągnięte zostaną przewidywane w celach kształcenia zmiany $\mathrm{w}$ wiadomościach, umiejętnościach i postawach ucznia ${ }^{32}$.

W powyższych rozważaniach dużą rolę odegrały założenia teorii wiadomości, którą w przypadku treści kształcenia odnosić można do pracy z wiadomościami wraz ze zmianami, jakie zachodzą w uczniu w efekcie tych czynności. W takim ujęciu treści są zbiorem „planowanych czynności ucznia wyznaczonych przez materiał nauczania i zaplanowaną zmianę psychiczną" ${ }^{33}$ i należałoby je interpretować w kontekście następujących elementów:

1) wiedzy, czyli materiału nauczania, jaki stanowi kontekst zmian psychicznych, będących hasłami programowymi, wiadomościami z zakresu obiektu poznania;

2) zmiany w wiadomościach ucznia oraz w jego umiejętnościach i systemie wartości;

3) czynności ucznia, które powodują, iż zmiany te zachodzą ${ }^{34}$.

Podobnie treści określa Bolesław Niemierko. Traktuje je jako system przewidzianych do opanowania czynności uczniów, określonych przez pryzmat celów kształcenia (o których decyduje wybrana taksonomia),

\footnotetext{
31 Ibidem.

32 K. Kruszewski, Wykorzystanie teorii wiadomości...

33 Idem, Program szkolny, [w:] K. Konarzewski (red.), Sztuka nauczania. Szkoła, Wydawnictwo Naukowe PWN, Warszawa 2002, s. 190. 
materiału kształcenia (podporządkowanego tematom lub działom programowym) oraz wymagań programowych (sklasyfikowanych według przyjętych poziomów ${ }^{35}$. Autor zauważa, iż czynności te mogą być efektem aktywności emocjonalnej lub poznawczej ucznia, natomiast to zachowanie między nimi równowagi, sprzyja wynikom uczenia się. Ponadto zwraca uwagę na zasadnicze różnice pomiędzy treścią kształcenia a treścią uczenia się. Jego zdaniem, ta druga determinowana jest głównie przez indywidualne cechy osoby uczącej się ${ }^{36}$.

W współczesnych analizach treści kształcenia warto uwzględnić założenia wieloparadygmantyczności ${ }^{37}$. To właśnie teoria Thomasa Kuhna, ujawniając zmienność nauki, może okazać się przydatna w podjęciu takiego zadania. Trzeba zgodzić się z Dorotą Klus-Stańską, iż w podejściu do edukacji, w myśleniu o uczeniu się i nauczaniu warto ujawniać różnorodność podejść. Jak pisze, to „różnorodność jest najbardziej witalnym motorem rozwoju edukacji i jedyną szansą na zaspokajanie potrzeb jednostek i społeczeństwa. Dramatem polskiej szkoły nie jest jej taka a nie inna postać, jest nim jej unifikacja”38. Stąd to zmiany stać się powinny kluczową kwestią w rozważaniach nad procesem kształcenia, a więc i nad treściami. Niestety jednak, nie zawsze zmiany powodują poprawę edukacji i lepszą jej jakość. Jak pisze Zbigniew Kwieciński, polski system edukacyjny wymaga gruntownego przeglądu, wciąż jest bowiem niespójny i przednowoczesny. Dlatego też potrzebna jest zmiana myślenia o edukacji ${ }^{39}$. Z całą pewnością, dotyczy to również treści. Tadeusz Lewowicki właśnie w edukacji, a dokładnie w wiedzy jako jej narzędziu, poszukuje dróg prowadzących do sprostania wyzwaniom, jakie stawia przed nami świat. Jednak - jak zauważa - poważną barierą w procesie przygotowywania ludzi do podejmowania tych wyzwań, a jednocześnie powodem, pretekstem rodzącej się krytyki wobec samego systemu edukacji, jest zbyt silne orientowanie się na tradycyjnych wzorach zachowań, w których dominuje

\footnotetext{
35 B. Niemierko, Cele kształcenia, [w:] K. Kruszewski (red.), Sztuka nauczania...

36 B. Niemierko, Kształcenie szkolne. Podręcznik skutecznej dydaktyki, Wydawnictwa Akademickie i Profesjonalne, Warszawa 2007.

37 Por. D. Klus-Stańska, Paradygmaty dydaktyki, Wydawnictwo Naukowe PWN, Warszawa 2018.

38 Ibidem, s. 10.

39 Z. Kwieciński, Edukacja wobec blokad systemu kulturowego, „Edukacja Międzykulturowa" 2018, nr 2, s. 17.
} 
schematyzm w metodach kształcenia, formach pracy, gdzie widoczny jest nadmiar encyklopedycznej wiedzy o przeszłości, a wątłej o świecie współczesnym i jego przemianach ${ }^{40}$.

Wiele refleksji, ale i istotnych odniesień do treści, można odnaleźć we współczesnych analizach procesu uczenia się. Jednym z intersujących, ale i bardzo ważnych dla dydaktyki jest z całą pewnością koncepcja tzw. nowej kultury uczenia się, której założenia bliskie są wielu nowoczesnym koncepcjom, jaką jest np. konstruktywizm ${ }^{41}$. Doskonale wypełniają tę przestrzeń podejmowane i znane badania dotyczące takich kategorii jak: wiedza ${ }^{42}$, informacja ${ }^{43}$, język ${ }^{44}$, a nawet zjawisko efektów kształcenia, obecnych od jakiegoś czasu w dokumentacji programowej współczesnych szkół. Powyższe kwestie są coraz częściej poruszane we współczesnej literaturze pedagogicznej, co wynika ze specyfiki i uwarunkowań obecnie rozumianego procesu kształcenia, jak i ujawnienia istniejącego konfliktu pomiędzy teorią dotyczącą funkcjonowania wiedzy szkolnej a praktyką dydaktyczną ${ }^{45}$, gdzie - niestety - treści wciąż stanowią gotowy do przekazania pakiet wiedzy. A przecież powinny one raczej podlegać nieustannym interpretacjom, procesom tworzenia znaczeń, których sednem jest komunikacja, dialog i porozumiewanie się ${ }^{46}$. Słusznie zauważa więc Dorota Klus-Stańska, iż współczesna dydaktyka powinna w większym stopniu

40 T. Lewowicki, Przemiany oświaty, Wydział Pedagogiczny Uniwersytetu Warszawskiego, Warszawa 1994.

41 Szerzej na ten temat: J. Sacharczuk, A. Szwarc, Edukacja i inne procesy wspierajace proces kształtowania kompetencji międzykulturowych - ujęcie teoretyczne i praktyczne, „Kultura i Edukacja” 2020, nr 1.

42 Por. m.in. D. Klus-Stańska, Wiedza osobista uczniów jako punkt zwrotny w teorii i praktyce dydaktycznej, „Kwartalnik Pedagogiczny” 2019, nr 1; Eadem, Konstruowanie wiedzy w szkole, Wydawnictwo Uniwersytetu Warmińsko-Mazurskiego, Olsztyn 2000; S. Dylak, Architektura wiedzy w szkole, Difin, Warszawa 2013; Idem, Koniec „nauczania” czy nowy paradygmat dydaktyczny, [w:] L. Hurło, D. Klus-Stańska, M. Łojko (red.), Paradygmaty współczesnej dydaktyki, Oficyna Wydawnicza „Impuls", Kraków 2009.

43 Por. prace m.in. J. Morbitzera, K. Borawskiej-Kalbarczyk.

44 B. Gołębniak, G. Teusz, Edukacja poprzez język, Wydawnictwo CODN, Warszawa 1999.

45 K. Borawska-Kalbarczyk, Kompetencje informacyjne uczniów w perspektywie zmian szkolnego środowiska uczenia się, Wydawnictwo Akademickie Żak, Warszawa 2015.

46 T. Bauman, Uniwersytet wobec zmian społeczno-kulturowych, Wydawnictwo Uniwersytetu Gdańskiego, Gdańsk 2001, s. 119. 
zainteresować się „nie tym, w jakim stopniu uczniowie przyswoili treści programowe, ale tym, jak myślą i rozumieją rzeczywistość i jej elementy, jak się w nią angażują i jakie przewidują miejsce dla siebie w procesach społecznego tworzenia prawomocnej wiedzy"47. Bowiem dziś głównym zadaniem uczniów jest nie tylko analizowanie, rozumienie i zapamiętywanie dostarczanych im treści, które autorka ujmuje w kategoriach wiedzy zewnętrznej, stanowiącej element interesującego poznawczo modelu konstruowania wiedzy w szkole (przekazu pojęć i konstruowania znaczeń $)^{48}$. Jedna z tez, jaką stawia Dorota Klus-Stańska, dotyczy założenia „że tradycyjnie utrzymujące się sposoby opracowywania wiedzy w szkole mają charakter zniewalający ucznia pod względem tożsamościowym, intelektualnym i społecznym (...), że edukacyjne tradycje przekazu wiedzy mogą szkodzić uczniowskiemu poczuciu ja, uczniowskiemu rozumowi i relacjom między ludźmi uwikłanymi w kształcenie"49.

Powyższe rozważania $\mathrm{w}$ dużej mierze oparte są na zasadach konstruktywizmu, które to stanowić mogą doskonałą płaszczyznę dla współczesnych interpretacji i poszukiwań badawczych w zakresie treści kształcenia. Mogą również pełnić funkcje klamry spinającej wiele przedstawionych powyżej naukowych refleksji. Konstruktywizm, z racji swej wielowątkowości, ale i deformacji, jakim dziś podlega, nazwać można nie tyle teorią, ale „nurtem myślenia” ${ }^{2}$. Jego elementy obecne są w modelu psychokulturowej edukacji wspominanego już Jerome'a S. Brunera, który pisze:

konstrukcja rzeczywistości to produkt wytwarzania znaczenia, ukształtowany przez tradycję oraz przez kulturowe narzędzia sposobów myślenia. W tym sensie edukację należy spostrzegać jako wspomaganie młodzieży w uczeniu się użycia narzędzi do wytwarzania znaczeń i konstruowania rzeczywistości w celu lepszego przystosowania do świata, w którym

47 D. Klus-Stańska, Dydaktyka wobec chaosu pojęć i zdarzeń, Wydawnictwo Akademickie Żak, Warszawa 2010, s. 344-345.

48 Eadem, Paradygmaty dydaktyki...; Eadem, Konstruowanie wiedzy w szkole, Uniwersytet Warmińsko-Mazurski w Olsztynie, Olsztyn 2002.

49 Eadem, Wiedza, która zniewala - transmisyjne tradycje w szkolnej edukacji, „Forum Oświatowe" 2012, nr 1(46), s. 22.

50 Eadem, Dydaktyka wobec..., s. 345. 
żyje, oraz do rozpoczęcia skutecznego procesu jego modyfikacji, zgodnie z własnymi wymaganiami ${ }^{51}$.

Natomiast analizowanie procesu uczenia się w perspektywie kulturowej wymaga uwzględnienia wzajemnych relacji pomiędzy umysłem uczących się a kulturą, nastawionych na ustalenie i zrozumienie

czy i w jakim stopniu, dzieci mają świadomość swoich własnych procesów myślowych; jaka jest kultura uczenia się współczesnej polskiej szkoły na różnych jej etapach?, czy w kulturze uczenia się współczesnych klas szkolnych dzieci doświadczają sytuacji, w których są/stają się coraz bardziej świadome sposobów uczenia się, myślenia?, jaki „kulturowy zestaw narzędzi" przekazują uczącym się nauczyciele?, czy uczniowie dokonują refleksji nad własnym uczeniem, jakie jest ich poczucie sprawstwa?, czy organizowany proces nauczania-uczenia się w klasie szkolnej umożliwia uchwycenie dziecku różnic pomiędzy wiedzą osobistą a wiedzą, która jest uznawana w danej kulturze za obiektywną? ${ }^{52}$.

To te właśnie kulturowe konteksty uczenia się tworzą doskonałą przestrzeń do wykorzystania uczniowskiego potencjału umysłowego, dostarczenia narzędzi do uczenia się (m.in. takich jak rozumienie, wyjaśnianie, interpretacja), ale i umożliwią doświadczanie poczucia możliwości posłużenia się własnym rozumem ${ }^{53}$. Warto te konteksty uwzględnić w nowoczesnym myśleniu o treściach kształcenia.

W rozważaniach nad treścią kształcenia wiele uwagi poświęca się przede wszystkim temu, „w jaki sposób jest ona skonstruowana w warunkach kształcenia zinstytucjonalizowanego" ${ }^{4}$. Oczywiście, zgodzić się należy, iż w takich analizach bardzo ważne miejsce odgrywają takie aspekty, jak indywidualne czynności wynikające z kultury, ale i psychiki ucznia. To prawda, iż ważna jest też dziedzina wiedzy, której się

51 J.S. Bruner, Kultura edukacji, Wydawnictwo Universitas, Kraków 2006, s. 37-38.

52 E. Filipiak, „Produkty” kultury uczenia się uczniów szkoły podstawowej i gimnazjum, „Forum Oświatowe” 2012, nr 1(46), s. 160.

53 "Eadem, Z Wygotskim i Brunerem w tle: Słownik pojęć kluczowych, Wydawnictwo Uniwersytetu Kazimierza Wielkiego, Bydgoszcz 2011.

54 M. Uljens, Dydaktyka szkolna, [w:] B. Śliwerski (red.), Pedagogika, t. 2: Pedagogika wobec edukacji, polityki oświatowej i badań naukowych, GWP, Gdańsk 2006, s. 123. 
naucza, której one dotyczą, z którą mamy do czynienia ${ }^{55}$. Jednak wydaje się, iż wciąż jeszcze we współczesnej literaturze pedagogicznej zbyt mało uwagi przykłada się do ujęcia terminologicznego treści. Jak przed laty pisał Krzysztof Kruszewski:

Tylko niewielu autorów piszących o treści kształcenia definiuje to pojęcie inaczej niż zdawkowo albo jednocześnie określa jego zakres. Najczęściej można jedynie domyślać się znaczenia, jakie pojęciu treści nadał autor, jeżeli dociekać, jakie z przyjętego znaczenia płyną konsekwencje; różny bowiem będzie zakres analizowanych zjawisk, różne układy zmiennych, różna metoda badań, różne wnioski i różna podstawa teoretyczna. (...) Znaczenie terminu treść kształcenia, w jakim używa go jakiś autor, da się wyprowadzić z tego, jak proponuje on treść dobierać, układać, badać56.

Wiele $\mathrm{z}$ tych kwestii jest - z całą pewnością - i dziś wartych uwagi. Pomimo tego, iż obecnie większą popularnością cieszą się konteksty, w jakich o treściach możemy myśleć (za przykład niech posłużą kontrowersje wokół tworzenia podstawy programowej, jak i jej obecnego kształtu), pamiętajmy o naukowym dorobku pedagogiki. Już przed wieloma laty ważną refleksją podzielił się z nami Krzysztof Kruszewski, przypominając, iż to historia uczy pokory. Zatem „poszukujmy w przeszłości materiału do refleksji o naturze postępu w dydaktyce"57.

\begin{abstract}
The content of education is now one of the most important elements of the education process. The concept of educational content is presented in the article, based on an analysis of available literature. Much attention was also paid to the criteria for their selection in the educational process. These issues are presented in the context of changes to the educational process affecting the main elements of education.
\end{abstract}

\title{
Bibliografia
}

Bauman T., Uniwersytet wobec zmian społeczno-kulturowych, Wydawnictwo Uniwersytetu Gdańskiego, Gdańsk 2001.

\footnotetext{
Ibidem.

K. Kruszewski, Zmiana i wiadomość..., s. 110-111.

Ibidem, s. 287.
} 
Borawska-Kalbarczyk K., Kompetencje informacyjne uczniów w perspektywie zmian szkolnego środowiska uczenia się, Wydawnictwo Akademickie Żak, Warszawa 2015.

Bruner J.S., Kultura edukacji, Wydawnictwo Universitas, Kraków 2006.

Dylak S., Architektura wiedzy w szkole, Difin, Warszawa 2013.

Dylak S., Koniec „nauczania” czy nowy paradygmat dydaktyczny, [w:] L. Hurło, D. Klus-Stańska, M. Łojko (red.), Paradygmaty współczesnej dydaktyki, Oficyna Wydawnicza „Impuls”, Kraków 2009.

Filipiak E., Z Wygotskim i Brunerem w tle: Słownik pojęć kluczowych, Wydawnictwo Uniwersytetu Kazimierza Wielkiego, Bydgoszcz 2011.

Filipiak E., „Produkty” kultury uczenia się uczniów szkoły podstawowej i gimnazjum, „Forum Oświatowe” 2012, nr 1 (46).

Gołębniak B., Teusz G., Edukacja poprzez język, Wydawnictwo CODN, Warszawa 1999.

Hessen S., Struktura i treść szkoły współczesnej (zarys dydaktyki ogólnej), Nasza Księgarnia, Warszawa 1947.

Klus-Stańska D., Dydaktyka wobec chaosu pojęć i zdarzeń, Wydawnictwo Akademickie Żak, Warszawa 2010.

Klus-Stańska D., Konstruowanie wiedzy w szkole, Uniwersytet Warmińsko-Mazurski w Olsztynie, Olsztyn 2002.

Klus-Stańska D., Konstruowanie wiedzy w szkole, Wydawnictwo Uniwersytetu Warmińsko-Mazurskiego, Olsztyn 2000.

Klus-Stańska D., Paradygmaty dydaktyki, Wydawnictwo Naukowe PWN, Warszawa 2018.

Klus-Stańska D., Wiedza, która zniewala - transmisyjne tradycje w szkolnej edukacji, „Forum Oświatowe” 2012, nr 1(46).

Klus-Stańska D., Wiedza osobista uczniów jako punkt zwrotny $w$ teorii i praktyce dydaktycznej, „Kwartalnik Pedagogiczny” 2019, nr 1.

Konarzewski K., Reforma oświaty. Podstawa programowa i warunki kształcenia, Instytut Spraw Publicznych, Warszawa 2004.

Kruszewski K. (red.), Sztuka nauczania. Czynności nauczyciela, Wydawnictwo Naukowe PWN, Warszawa 2007.

Kruszewski K., Od tłumacza, [w:] D.F. Walker, J.F. Soltis, Program i cele kształcenia, Wydawnictwa Szkolne i Pedagogiczne, Warszawa 2000.

Kruszewski K., Program szkolny, [w:] K. Konarzewski (red.), Sztuka nauczania. Szkoła, Wydawnictwo Naukowe PWN, Warszawa 2002.

Kruszewski K., Wykorzystanie teorii wiadomości w studiach nad treściami kształcenia, [w:] M. Berge, T. Lewowicki (red.), Optymalizacja treści i procesu kształcenia, Wydawnictwo Uniwersytetu Warszawskiego, Warszawa 1992. 
Kruszewski K., Zmiana i wiadomość. Perspektywa dydaktyki ogólnej, Państwowe Wydawnictwo Naukowe, Warszawa 1987.

Kupisiewicz C., Charakter i treść kształcenia powszechnego: podstawowego $i$ średniego, [w:] M. Berge, T. Lewowicki (red.), Optymalizacja treści i procesu kształcenia, Wydawnictwo Uniwersytetu Warszawskiego, Warszawa 1992.

Kupisiewicz C., Projekty reform edukacyjnych w Polsce, Wydawnictwo Naukowe PWN, Warszawa 2006.

Kwieciński Z., Edukacja wobec blokad systemu kulturowego, „Edukacja Międzykulturowa” 2018, nr 2.

Lewowicki T., Przemiany oświaty, Wydział Pedagogiczny Uniwersytetu Warszawskiego, Warszawa 1994.

Milerski B., Śliwerski B. (red.), Pedagogika. Leksykon PWN, Wydawnictwo Naukowe PWN, Warszawa 2000.

Nawroczyński B., Zasady nauczania, Wydawnictwo Książnica - Atlas, Lwów - Warszawa 1930.

Niemierko B., Cele kształcenia, [w:] K. Konarzewski (red.), Sztuka nauczania. Szkoła, Wydawnictwo Naukowe PWN, Warszawa 2002.

Niemierko B., Kształcenie szkolne. Podręcznik skutecznej dydaktyki, Wydawnictwa Akademickie i Profesjonalne, Warszawa 2007.

Okoń W., Nowy słownik pedagogiczny, Wydawnictwo Akademickie Żak, Warszawa 2004.

Okoń W., Wprowadzenie do dydaktyki ogólnej, Wydawnictwo Akademickie Żak, Warszawa 2003.

Piotrowski E., Rola treści kształcenia w procesie nauczania, „Chowanna. Tom Jubileuszowy" 2009.

Program nauczania w szkole podstawowej, Państwowe Zakłady Wydawnictw Szkolnych, Warszawa 1959.

Sacharczuk J., Szwarc A., Edukacja i inne procesy wspierające proces kształtowania kompetencji międzykulturowych - ujęcie teoretyczne i praktyczne, „Kultura i Edukacja” 2020, nr 1.

Siemak-Tylikowska A., Treści nauczania - teorie doboru treści kształcenia, [w:] W. Pomykało (red.), Encyklopedia pedagogiczna, Wydawnictwo Naukowe PWN, Warszawa 1997.

Sośnicki K., Zarys dydaktyki, Wydawnictwa Książek Szkolnych Kuratorjum Okręgu Szkolnego Lwowskiego, Lwów 1925.

Suchodolski B., Wstęp, [w:] J.A. Komeński, Wielka dydaktyka, Wydawnictwo Polskiej Akademii Nauk, Wrocław 1956. 
Szwarc A., Treści kształcenia jako element programu szkolnego w pogladach wybitnych pedagogów pierwszej połowy XX wieku, „Przegląd Historyczno-Oświatowy" 2019, nr 3-4.

Uljens M., Dydaktyka szkolna, [w:] B. Śliwerski (red.), Pedagogika, t. 2: Pedagogika wobec edukacji, polityki oświatowej i badań naukowych, GWP, Gdańsk 2006. 